\title{
Do People Naturally Cluster into Liberals and Conservatives?
}

\author{
Jason Weeden ${ }^{1} \cdot$ Robert Kurzban $^{2}$
}

Published online: 12 November 2015

(C) Springer International Publishing 2015

\begin{abstract}
Many researchers have attempted to link evolutionary notions to political psychology by proposing a natural tendency for people to cluster into liberals and conservatives across various social and economic opinion domains. We review evidence showing that, in contrast, for the large majority of Americans, racial and economic opinions are only trivially correlated with opinions regarding matters of lifestyle and religious fundamentalism. The key exception is a group that does, in fact, show reasonably robust ideological alignment across diverse domains: whites with high levels of human capital (measured by education and test performance). Further, since the early 1980s, while the US public as a whole has increasingly tended to choose liberal/conservative labels and political parties in line with their issue opinions, substantial increases in cross-issue correlations have occurred only among whites with high levels of human capital. Nonetheless, mass public opinion is not unstructured-it maintains an underlying coherence grounded in domainspecific demographic connections relating to different opinion areas.
\end{abstract}

Electronic supplementary material The online version of this article (doi:10.1007/s40806-015-0036-2) contains supplementary material, which is available to authorized users.

Jason Weeden

jasonweeden5@gmail.com

1 Pennsylvania Laboratory for Experimental Evolutionary Psychology, 432 N St. NW, Apt. B, Washington, DC 20001, USA

2 Department of Psychology, Pennsylvania Laboratory for Experimental Evolutionary Psychology, University of Pennsylvania, 3720 Walnut St., C3, Philadelphia, PA 19104, USA
Keywords Ideology $\cdot$ Public opinion $\cdot$ Domain-specific · Political parties

People have vast differences of opinion on a range of topicsincome redistribution, abortion, immigration, healthcare, same-sex marriage, criminal justice, and more. Here, we look at explanations for these differences through an evolutionary lens, an approach that has been steadily gaining traction among political psychologists (Lopez \& McDermott 2012; Petersen 2015), contrasting our approach with other candidate explanations.

In particular, one predominant explanation for differences in political opinions is that they derive from people's basic left-right or liberal-conservative orientations (Haidt 2012; Hibbing, Smith, \& Alford 2013, 2014; Jost, Federico, \& Napier 2009; Pinker 2002; Tuschman 2013), a view we will refer to as the General Orientations Model. Proponents of this view stress the "ancient and universal" reality of the liberalconservative division (Hibbing, Smith, \& Alford 2014; see also Pinker 2002; Tuschman 2013), seeing the psychological origins of individuals' positions on this continuum as stemming from basic personality features such as openness and conscientiousness (Haidt 2012; Hibbing, Smith, \& Alford 2013; Jost, Federico, \& Napier 2009; Pinker 2002), conceptions of human nature (Pinker 2002; Tuschman 2013), moral foundations (Haidt 2012), negativity bias (Hibbing, Smith, \& Alford 2014), and so on.

In contrast to the General Orientations Model, we have proposed what we'll call a Domain-Specific Model of public opinion (Weeden \& Kurzban 2014). The model begins with the idea that people have goals that are advanced or undermined by different policies affecting the redistribution of resources and support for the needy, meritocracy and discrimination regimes governing social status, and sexual and 
reproductive lifestyles. Our view is that people are generally able to identify the rough contours of their adaptive interests with respect to these diverse policy domains - often related to their demographic features - and tend to take positions consistent with these interests; to advance these interest-based goals, people might endorse or affiliate with ideological and party coalitions that seek to implement often unrelated policies (Weeden \& Kurzban 2014). Petersen's (2015) view of the evolutionary political psychology of issue opinions is parallel to our own: "Political judgments are ... informed by at least two general types of evolved mechanisms: first, adaptations designed to judge the fitness consequences for the self of the content of rules (in part, due to the effects on valuable others) and second, adaptations designed to coordinate judgments with other coalitional members, independently of rule content."

The General Orientations Model supposes that humans naturally cluster into liberals and conservatives; our DomainSpecific Model does not. So, for example, we have argued that views on lifestyle issues (abortion, marijuana legalization, and so on) derive in large part from strategic sexual and reproductive conflicts that are closely related to religiosity (Kurzban 2010; Kurzban, Dukes, \& Weeden 2010; Weeden 2003; Weeden, Cohen, \& Kenrick 2008). Similarly, we have proposed that views on social status policies are largely driven by group identities and human capital that determine whether one benefits from discriminatory or meritocratic rules when it comes to particular target groups. In addition, we've suggested that views on government economic redistribution relate more to socioeconomic status and the extent to which one's private support network reduces one's need for public safety nets (Weeden \& Kurzban 2014). When opinions across such issue domains align in ideologically consistent waysthat is, when individuals are either liberal on various types of issues or conservative on various types of issues - we argue, echoing Petersen's (2015) view, that it's typically either, first, because the underlying domain-specific interests happen to align or, second, because the political coalitions happen to become organized such that various liberal constituencies are allied in competition against various conservative constituencies.

This point is easy to miss. The use of the terms "liberal" and "conservative" to describe disagreements over lifestyles, social status regimes, economic issues, and so on encourages a kind of intuitive reification of ideological categories. If "liberals" are pro-choice and "liberals" are in favor of expanded economic safety nets, then it seems natural to suppose that the people who are pro-choice tend as well to be the people in favor of expanded safety nets. Further, currently in many places, political competitions are organized around party coalitions that adopt either liberal positions on many issues or conservative positions on many issues. Perhaps nowhere is this more apparent than in the USA. The Democratic and
Republican parties hold long-standing contrasting views on issues pitting economic security for the poor against the interests of business and the wealthy. However, in the past halfcentury, the parties have become divided as well by civil rights for racial and religious minorities, the availability of family planning services, immigration policies, and more (Noel 2013). Though it wasn't always so, the Democratic coalition has become most representative of individuals with liberal views across a wide variety of issues, while the Republican coalition has become most representative of individuals with conservative views across these many issues (Hussey 2012).

Observers might use the same labels to describe various opinion constituencies, and those constituencies might be represented by the same coalitions, but intra-coalitional constituencies might still maintain diverse opinions. So, for example, supporters of labor unions might favor the Democratic coalition and supporters of civil rights for homosexuals might also favor the Democratic coalition. We might call both of these animating concerns "liberal." However, from these facts alone, we don't know whether people who support labor unions tend to be the same people who support civil rights for homosexuals. The General Orientations Model supposes that they are, for deep psychological reasons; our DomainSpecific Model views these as separate interest-driven opinion domains that might or might not tend to align, depending on demographic and coalitional features.

Figure 1 provides a simple representation of possible patterns of ideology in public opinion. Along the left-to-right axis, people vary in whether they use the terms "liberal" and "conservative" consistently to describe their issue opinions. It's possible, for example, that many people might hold generally liberal, generally conservative, or thoroughly mixed views without also giving themselves matching ideological labels. Along the top-to-bottom axis, people vary in their tendency to have opinions that fall tightly into liberal or conservative clusters. It's possible that in a given population various areas of policy opinion simply don't tend to correlate with one another, such that, for example, views on religious issues are not typically consistently related to views on economic issues.

Combining outcomes across the two axes in Fig. 1 leads to a number of possibilities. A population might not consistently use liberal-conservative labels, and might show little ideological correspondence across issue domains - a region we've labeled "not ideological" in Fig. 1. In the opposite corner, a population might be "genuinely ideological," showing high use of liberal-conservative labels and a strong tendency for issue domains to correspond in line with a single liberalconservative dimension. A population could also be "nominally ideological," showing little underlying left-right correspondence between issue domains, yet where people nonetheless commonly use matching ideological labels to describe their overall issue opinions. Here, liberal-conservative labels can be thought of as post hoc descriptions rather than deep 


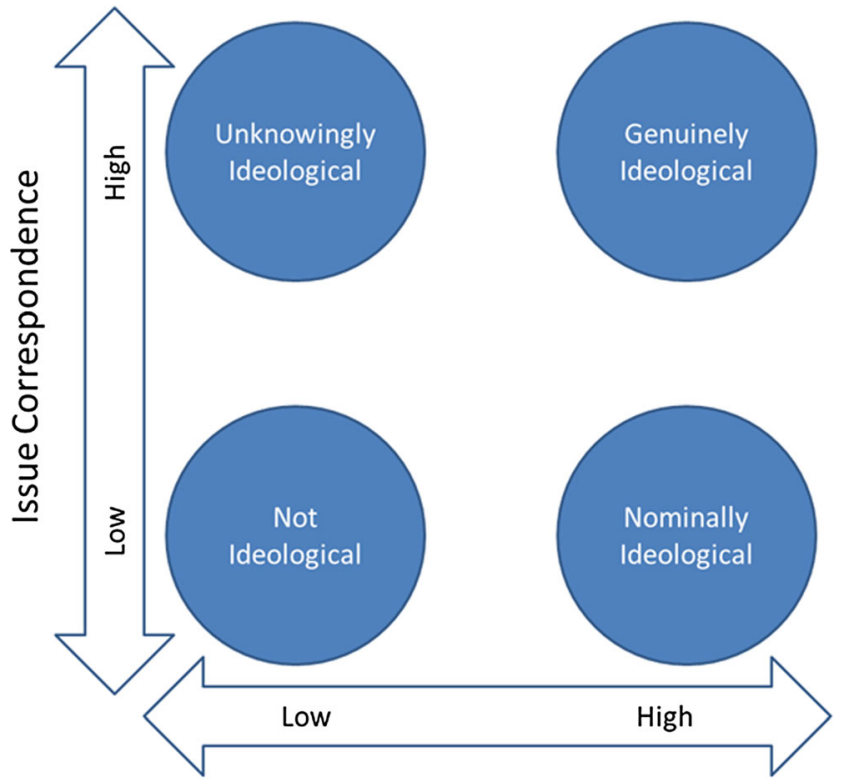

Use of Liberal-Conservative Labels

Fig. 1 Possible ideological outcomes in public opinion

psychological foundations. And, finally, a population could be "unknowingly ideological," showing little use of ideological labels, yet still containing individuals whose issue opinions across domains tend to follow an overall liberal-conservative dimension. Here, psychological forces work to align issue opinions, even though people don't typically label themselves accordingly.

The General Orientations Model supposes that people are either "unknowingly ideological" or "genuinely ideological"- that is, whether they label themselves so or not, people's views across issue domains tend to be driven broadly to the left or to the right by inherent psychological tendencies. The Domain-Specific Model, in contrast, supposes that the "unknowingly ideological" outcome is the least likely when considering issue domains without much interest-based demographic overlap. The likelihood of people being in the other regions depends in large part on the coalitional realities in a given place and time. When ideological labels aren't commonly used and don't describe operative coalitions (as, for example, in the USA in the middle of the twentieth century), we might find much of the population "not ideological"failing to demonstrate widespread issue correspondence or consistent use of ideological labels. When ideological labels become common, and particularly when such labels describe real-world political coalitions, people are more likely to be in the "nominally ideological" and "genuinely ideological" regions.

A long line of political science-having its most direct origins in Converse (1964) - notes that members of the US general public tend not to have issue opinions that line up on a single left-right axis (Feldman \& Johnston 2014; Stimson 1975; Treier \& Hillygus 2009) and often don't use ideological terms in ways that reflect their issue opinions (Claassen, Tucker, \& Smith 2015; Ellis \& Stimson 2012). The "genuinely ideological" segments of the population tend to be limited to relatively narrow slices of the public who are more politically involved, are better educated, possess greater political knowledge, and so on (Feldman \& Johnston 2014; Jacoby 1991; Jessee 2012).

Yet, disagreements within political science persist. Some researchers claim that, in fact, the general public shows substantial liberal-conservative issue correspondence across various opinions (Jessee 2012; Jost, Federico, \& Napier 2009). An interesting question is why this debate, which ought to be empirically tractable - how much ideological coherence is there? - persists. One possible contribution to the disagreement has to do with the description of the primary division in public opinion as "economic" versus "social," with various researchers finding different levels of correlation between these groups of issues in public opinion (Carmines, Ensley, \& Wagner 2012; Feldman \& Johnston 2014; Hibbing, Smith, \& Alford 2014; Hussey 2012; Klar 2014; Verhulst, Hatemi, \& Eaves 2012). While the "economic" grouping is often justified, involving various issues relating to income redistribution and the provision of benefits for the needy, the "social" grouping might cast too wide a net, including issues relating to sexual lifestyles, religious fundamentalism, race, immigration, or criminal justice.

The primary problem with the "social" grouping, particularly with respect to the US public, is that while the demographic predictors of economic opinions indeed have little in common with the demographic predictors of opinions on religious issues, economic issues in fact share substantial demographic foundations with racial issues, linked primarily by the strong relationship of race with both opinion domains (Weeden \& Kurzban 2014). Thus, studies including affirmative action, the death penalty, or related issues as "social" issues might find more substantial relationships between "social" and "economic" issues (e.g., Verhulst, Hatemi, \& Eaves 2012) than studies limiting "social" issues to those relating to lifestyles and religious fundamentalism (e.g., Feldman \& Johnston 2014).

A domain-specific perspective can help avoid such problems by focusing attention on how particular political issues relate to different underlying real-life concerns. In the following analyses, we use the US General Social Survey from 1980 to 2014, a large and representative dataset, to investigate public opinion in relation to three issue domains: economic (relating to income redistribution and government assistance for the poor and unemployed), racial (relating to African Americans, the death penalty, and immigration), and religious (relating to religious fundamentalism, discrimination on the basis of religion and sexual orientation, abortion, birth control, premarital sex, pornography, and marijuana legalization). We first look at how these issue domains have correlated over time, both in the 
sample as a whole and broken out by human capital (combining education and test performance) and race, and how these issue domains have related to use of liberal/conservative labels and political party affiliations. We then examine how these issue domains relate to a small set of politically salient demographic features.

\section{Methods}

The US General Social Survey (GSS) sample from 1980 to 2014 contains 48,947 individuals, though all of our analyses derive from subsets of this sample, primarily driven by the fact that not all participants have been asked the same issue items in every wave. All GSS analyses below use a weight variable combining the GSS's OVERSAMP variable (relating to oversamples of African Americans in two waves) and WTSSALL variable (a weighting variable used to reorient the GSS data from a household-based probability sample to an individual-based sample), including for reported Ns.

Our ideology variable is a combination of the GSS's POLVIEWS and POLVIEWX variables, both recoded such that 0 is the middle or "don't know" value, 3 is the most conservative value, and -3 is the most liberal value. Party affiliation is based on the GSS's PARTYID variable, recoded such that 0 is independent or other party, 3 is strong Republican, and -3 is strong Democrat.

The three issue domains were constructed from 55 GSS items, each selected because they fit into our conceptions of religious, racial, or economic items. As described in the Methods Supplement for "Do People Naturally Cluster into Liberals and Conservatives?", we combined closely related items to lead to a more tractable set of 24 . We ran exploratory factor analyses on those 24 items, which produced three rotated factors indicating that the strongest loadings for the religious items were on one factor, the strongest loadings for the racial items were on another factor, and the strongest loadings for the economic items were on another factor. The religious items related to abortion, biblical literalism, homosexuality, marijuana legalization, pornography, premarital sex, rights for the anti-religious, school prayer, and teen birth control. The racial items related to race-based affirmative action, government help and spending for African Americans, racial discrimination, the death penalty, and immigration. The economic items related to government help and spending for the poor, government provision of jobs for and assistance to the unemployed, and income redistribution. We combined the items in each of the three domains (religious, racial, and economic), limited to participants with at least two underlying issue responses, and the final scales were then standardized (with mean of 0 and SD of 1), all as described in the Methods Supplement for "Do People Naturally Cluster into Liberals and Conservatives?".
For GSS demographic predictors, we included items relating to race (derived as described in Weeden \& Kurzban (2014, 237); our "white" measure includes only non-Hispanic whites), age (from the GSS's AGE variable), gender (from the GSS's SEX variable), education (from the GSS's EDUC and DEGREE variables), income (from the GSS's REALINC variable, with missing data estimated from a regression of the other demographic items), marital status (from the GSS's MARITAL variable), religion (from the GSS's RELIG variable), and church attendance (from the GSS's ATTEND variable, recoded to approximate the number of times per year in attendance). In addition, we calculated a human capital variable by combining education with the GSS's COMPREND variable as well as a number of factual and verbal test questions, including those described in Weeden \& Kurzban $(2014,237)$ along with the ALIKE1 to ALIKE8 series; the top $20 \%$ human capital designation typically captures those with 4-year college degrees, excluding some with poor test performance and including some non-degreed individuals with good test performance. Categorical variables (female, African American, Latino/Asian/other, graduate degree, married, Catholic, and not Christian, which includes those with no religious affiliation) were coded such that 1 indicates that the category applies and 0 indicates that it does not; other variables (age, education, income, church attendance) were standardized with mean of 0 and SD of 1 .

We also included a student sample surveyed across four large American universities in 2007 (originally used in Weeden, Cohen, \& Kenrick (2008)). The sample included 1064 individuals with an average age of $20.1(\mathrm{SD}=3.1)$, and was $59 \%$ female, $64 \%$ non-Hispanic white, and $7 \%$ African American. Ideology and party affiliation variables were both based on single 7-point scales, recoded as described above. Issue variables were based on items standardized and averaged as described above. The items for the economic measure were 7-point responses measuring support or opposition for higher taxes for the wealthy and greater support for the poor $(r=.43)$. The items for the racial measure were 7-point response measuring support or opposition to affirmative action, the death penalty, and immigration (median $r=.29$ ). The items for the religious measure were 7-point responses measuring biblical literalism and moral condemnation of homosexuality, casual sex, abortion, and recreational drug use (median $r=.47$ ).

Our demographic items for the student sample included measures of race, gender, religion, and church attendance. In addition, for income, we averaged two 7-point items, one relating to how wealthy/poor the respondent's family was while growing up and the other relating to whether the respondent expected a higher/lower income later in life. We also included a measure of the quality of the university from which the respondents were drawn, based on 2014 US News and World Report rankings (two of the schools ranked around 30 
and the other two were in the 100s) and reverse coded such that higher values represent more prestigious schools. Categorical variables (African American, female, Catholic, not Christian) were coded $1 / 0$ and other variables (school quality, income, church attendance) were standardized.

\section{Results}

Our first set of analyses investigated the extent to which our three issue domains correlated with one another in different time periods (1980 to 1991, 1993 to 2002, and 2004 to 2014). In line with prior analyses indicating that better educated whites have distinct ideological patterns (Gelman 2015; Weeden \& Kurzban 2014), we included splits based on race and human capital. Table 1 provides correlations among the religious, racial, and economic issue scales.

As shown in Table 1, racial and economic opinions often correlated strongly. However, religious opinions were often only trivially related to racial and economic opinions. The strongest tendency towards robust liberal-conservative issue relationships was among whites with top $20 \%$ human capital in the years 2004 to 2014, where religious and economic opinions correlated at .36 and religious and racial opinions at .39; for white college students in 2007, religious and economic opinions correlated at .17 and religious and racial opinions at .24 . In contrast, the remainder of the GSS sample (including both non-whites and anyone with bottom $80 \%$ human capital) as well as the nonwhite college students showed religious opinions correlating near zero with economic opinions and religious opinions correlating at trivial levels with racial opinions. Indeed, religious opinions were not significantly correlated with economic opinions in any sample of non-whites. These results provide prima facie evidence that substantial liberal-conservative issue correspondence is not pervasive. In addition, while GSS whites with high human capital in 2004 to 2014 showed substantial issue correlations across domains, the correlations within this group were notably lower in earlier periods, from 1993 to 2002 and from 1980 to 1991, particularly for correlations between religious opinions and economic opinions.

Next we investigated the extent to which the issue domains related to the respondents' own use of overall liberalconservative labels to describe their political positions. Table 2 shows the results of multiple regressions, reporting unstandardized coefficients using standardized issue scales to predict 7point ideological self-placements (centered at 0 , with higher values more conservative and lower values more liberal). We split the GSS sample into the same three time periods as the prior analyses and examined separately the full sample, whites with top $20 \%$ human capital, and others in the sample (including both whites with bottom $80 \%$ human capital and non-whites); we also included our student sample from 2007, split into whites and non-whites. The "Lib-Con distance" values are summary measures answering the question: Comparing those with consistently conservative issue opinions ( +1 for each domain) and those with consistently liberal issue opinions ( -1 for each domain), how many units apart does the model predict they are on average in ideological self-placements on a 7-point scale?

Table 2 shows a number of key results. First, all the issue domains make independent contributions to ideological selfplacements. Second, whites with high human capital (including white college students) show substantially more consistency than others do in their use of ideological labels in relation to their issue opinions. Third, the use of politically consistent ideological labels has been increasing over time across the entire GSS sample.

Table 3 presents the same analyses for political party affiliations rather than ideological labels (with party affiliations also on a 7-point scale centered at 0 , with higher values indicating stronger Republican affiliation and lower values indicating stronger Democratic affiliation). As with ideological labels, the correspondence between issue opinions and party affiliations has been increasing over time. While economic opinions have been strongly related to party affiliations over the entire survey period, religious and racial opinions have become increasingly related to party affiliations over time. Also as with ideological labels, the correspondence between issue opinions and party affiliations was substantially higher among whites with high levels of human capital (including white college students).

Our remaining analyses used demographic information to predict the three issue opinion domains. For the GSS sample, we ran multiple regressions predicting our three issue scales with a small set of demographic items separately for whites with top $20 \%$ human capital and everyone else (including whites with bottom $80 \%$ human capital and all non-whites). Table 4 presents the results for whites with top $20 \%$ human capital and Table 5 presents the results for everyone else, reporting unstandardized regression coefficients.

As shown in Tables 4 and 5, the dominant demographic predictors of religious opinions were church attendance and religion - Protestants and (to a lesser degree) Catholics with high levels of church attendance were substantially more conservative on these issues than non-Christians with low levels of religious service attendance. In addition, education and age were substantial predictors of religious opinions, with less educated and older participants more conservative than more educated and younger ones. Human capital differences showed up as well in comparing the "constants" across Tables 4 and 5, indicating that whites with high levels of human capital were substantially more liberal than whites with bottom $80 \%$ human capital, all else equal. Items such as race, gender, and income were relatively trivial predictors of religious opinions.

For racial opinions, the single dominant predictor was race. As shown in Table 5, African Americans, all else equal, were 1.25 standard deviations to the left of whites with bottom $80 \%$ 
Table 1 Correlations among religious, racial, and economic issue opinion domains

\begin{tabular}{|c|c|c|c|c|}
\hline & $N$ & $\begin{array}{l}\text { Religious- } \\
\text { economic }\end{array}$ & $\begin{array}{l}\text { Religious- } \\
\text { racial }\end{array}$ & $\begin{array}{l}\text { Racial- } \\
\text { economic }\end{array}$ \\
\hline \multicolumn{5}{|l|}{ All } \\
\hline 1980-2014 & 35,313 to 44,522 & .03 & .13 & .41 \\
\hline \multicolumn{5}{|l|}{ All } \\
\hline 1980-1991 & 13,762 to 17,114 & $-.01 *$ & .11 & .38 \\
\hline 1993-2002 & 12,270 to 14,507 & .04 & .11 & .42 \\
\hline 2004-2014 & 9280 to 12,901 & .08 & .14 & .45 \\
\hline \multicolumn{5}{|c|}{ Top $20 \%$ human capital } \\
\hline 1980-1991 & 2283 to 2757 & .18 & .23 & .55 \\
\hline 1993-2002 & 2534 to 2991 & .20 & .28 & .57 \\
\hline 2004-2014 & 2165 to 3013 & .31 & .33 & .60 \\
\hline \multicolumn{5}{|c|}{ Bottom $80 \%$ human capital } \\
\hline 1980-1991 & 11,478 to 14,357 & $-.01 *$ & .07 & .37 \\
\hline 1993-2002 & 9734 to 11,514 & .03 & .05 & .40 \\
\hline 2004-2014 & 7115 to 9888 & .04 & .05 & .42 \\
\hline \multicolumn{5}{|l|}{ White } \\
\hline 1980-1991 & 11,427 to 14,227 & $.01 *$ & .16 & .31 \\
\hline 1993-2002 & 9687 to 11,421 & .07 & .19 & .37 \\
\hline 2004-2014 & 6447 to 8958 & .17 & .27 & .42 \\
\hline \multicolumn{5}{|l|}{ Non-white } \\
\hline 1980-1991 & 2335 to 2886 & $.00^{*}$ & .06 & .31 \\
\hline 1993-2002 & 2583 to 3086 & $.00 *$ & $.00^{*}$ & .31 \\
\hline 2004-2014 & 2833 to 3943 & $-.03 *$ & $-.03 *$ & .35 \\
\hline \multicolumn{5}{|c|}{ Top $20 \%$; white } \\
\hline 1980-1991 & 2110 to 2541 & .19 & .26 & .55 \\
\hline 1993-2002 & 2238 to 2651 & .24 & .32 & .57 \\
\hline 2004-2014 & 1815 to 2504 & .36 & .39 & .61 \\
\hline \multicolumn{5}{|l|}{ Others } \\
\hline 1980-1991 & 11,651 to 14,573 & $.00^{*}$ & .08 & .37 \\
\hline 1993-2002 & 10,030 to 11,854 & .03 & .06 & .40 \\
\hline 2004-2014 & 7465 to 10,398 & .05 & .06 & .42 \\
\hline \multicolumn{5}{|l|}{ White students } \\
\hline 2007 & 667 to 671 & .17 & .24 & .40 \\
\hline \multicolumn{5}{|c|}{ Non-white students } \\
\hline 2007 & 381 to 384 & $.00 *$ & $.01 *$ & .28 \\
\hline
\end{tabular}

${ }^{*} p>.01 ;$ all other $p$ values $<.01$

human capital in racial opinions. There also was a substantial distance between Christians (more conservative) and nonChristians (less conservative) on racial opinions among whites with top $20 \%$ human capital, differences that were more modest among the rest of the population. In contrast, church attendance, age, and income made virtually no predictive contribution in either group.

For economic opinions, race and socioeconomic status were the primary predictors, with whites and those with higher incomes and more education substantially more conservative than non-whites (especially African Americans) and those with lower incomes and less education. A key exception to the socioeconomic pattern was the negative coefficient (indicating more liberal views) for graduate degrees among whites with top $20 \%$ human capital. Across race and education, then, the most conservative group was whites with top $20 \%$ human capital but not graduate degrees; whites with graduate degrees were similar to whites with middle levels of education, all else equal. While church attendance and age were trivial predictors of economic opinions in both samples, religion was again a major predictor among whites with top $20 \%$ human capital but was a relatively modest predictor among the rest of the population.

Table 6 provides a similar analysis of demographic predictors of political opinions in our student sample, split into whites and non-whites. For religious issues, the major predictors were church attendance as well as, to a far greater degree among whites than non-whites, non-Christian versus Christian religion. On racial opinions, the most substantial predictor was race, as indicated by the differing "constants" of whites and non-whites as well as the coefficient for African Americans among non-whites; in sum, all else equal, African Americans were almost a full standard deviation to the left of whites on racial opinions. In addition, non-Christian versus Christian religion was a substantial predictor of racial opinions for whites but not non-whites. For economic opinions, the major predictors were income (particularly for whites) and race (where, summing across constants and the coefficient for African Americans, African Americans were about a half standard deviation to the left of whites, all else equal) - in sum, then, those most conservative on economic opinions were white students with higher incomes, while those most liberal were African Americans with lower incomes. Religion was not a significant predictor of economic opinions among either whites or non-whites. On a final note, similar to the effect of graduate degrees among whites with top $20 \%$ human capital in the GSS sample, students at higher quality schools tended to be more liberal across the board, all else equal, than students at lower quality schools. The one exception was that school quality was non-significant in predicting economic opinions among non-white students.

\section{Discussion}

Do people naturally cluster into liberals and conservatives? Our analyses suggest the answer is no. Excluding nonHispanic whites with high levels of human capital, there was little or no correlation between people's opinions on religious issues and their opinions on racial and economic issues. While the divergence in opinion domains is often described as "social" versus "economic," the key contrast is really between religious and racial/economic. Opinions on social issues 
Table 2 Ideological labels predicted with issue opinions

\begin{tabular}{|c|c|c|c|c|c|}
\hline & All & $\begin{array}{l}\text { Top } 20 \% \\
\text { white }\end{array}$ & Others & White students & $\begin{array}{l}\text { Non-white } \\
\text { students }\end{array}$ \\
\hline \multicolumn{6}{|l|}{ 1980-1991 } \\
\hline Religious & $.31(.011)$ & $.48(.025)$ & $.27(.012)$ & & \\
\hline Racial & $.14(.011)$ & $.29(.028)$ & $.11(.012)$ & & \\
\hline Economic & $.24(.011)$ & $.43(.030)$ & $.19(.012)$ & & \\
\hline$N$ & 13,678 & 2104 & 11,574 & & \\
\hline $\mathrm{R}^{2}$ & .123 & .398 & .082 & & \\
\hline Lib-Con distance & 1.38 & 2.40 & 1.14 & & \\
\hline \multicolumn{6}{|l|}{ 1993-2002 } \\
\hline Religious & $.43(.011)$ & $.59(.024)$ & $.39(.013)$ & & \\
\hline Racial & $.17(.012)$ & $.34(.028)$ & $.13(.013)$ & & \\
\hline Economic & $.28(.012)$ & $.42(.028)$ & $.23(.014)$ & & \\
\hline $\mathrm{N}$ & 12,229 & 2236 & 9991 & & \\
\hline $\mathrm{R}^{2}$ & .194 & .461 & .137 & & \\
\hline Lib-Con distance & 1.76 & 2.70 & 1.50 & & \\
\hline \multicolumn{6}{|l|}{ 2004-2014 } \\
\hline Religious & $.45(.012)$ & $.63(.026)$ & $.40(.014)$ & $.79(.045)$ & $.61(.071)$ \\
\hline Racial & $.25(.015)$ & $.27(.031)$ & $.22(.017)$ & $.38(.048)$ & $.24(.079)$ \\
\hline Economic & $.33(.013)$ & $.52(.028)$ & $.27(.015)$ & $.48(.047)$ & $.41(.079)$ \\
\hline $\mathrm{N}$ & 9228 & 1814 & 7414 & 664 & 378 \\
\hline $\mathrm{R}^{2}$ & .264 & .567 & .187 & .529 & .251 \\
\hline Lib-Con distance & 2.06 & 2.84 & 1.78 & 3.30 & 2.52 \\
\hline
\end{tabular}

All $p$ values $<.01$; standard errors are in parentheses

\begin{tabular}{|c|c|c|c|c|c|}
\hline & All & $\begin{array}{l}\text { Top } 20 \% \text {; } \\
\text { white }\end{array}$ & Others & $\begin{array}{l}\text { White } \\
\text { students }\end{array}$ & $\begin{array}{l}\text { Non-white } \\
\text { students }\end{array}$ \\
\hline \multicolumn{6}{|l|}{ 1980-1991 } \\
\hline Religious & $.03 *(.017)$ & $.39(.039)$ & $-.01 *(.019)$ & & \\
\hline Racial & $.24(.017)$ & $.44(.044)$ & $.22(.019)$ & & \\
\hline Economic & $.53(.018)$ & $.54(.047)$ & $.47(.020)$ & & \\
\hline $\mathrm{N}$ & 13,720 & 2108 & 11,612 & & \\
\hline $\mathrm{R}^{2}$ & .106 & .258 & .083 & & \\
\hline Lib-Con distance & 1.60 & 2.74 & 1.36 & & \\
\hline \multicolumn{6}{|l|}{ 1993-2002 } \\
\hline Religious & $.20(.016)$ & $.51(.036)$ & $.15(.019)$ & & \\
\hline Racial & $.39(.018)$ & $.37(.042)$ & $.38(.020)$ & & \\
\hline Economic & $.51(.018)$ & $.71(.042)$ & $.42(.020)$ & & \\
\hline $\mathrm{N}$ & 12,186 & 2229 & 9956 & & \\
\hline $\mathrm{R}^{2}$ & .165 & .360 & .126 & & \\
\hline Lib-Con distance & 2.20 & 3.18 & 1.90 & & \\
\hline \multicolumn{6}{|l|}{ 2004-2014 } \\
\hline Religious & $.30(.017)$ & $.70(.038)$ & $.24(.020)$ & $.69(.052)$ & $.25(.079)$ \\
\hline Racial & $.47(.021)$ & $.36(.046)$ & $.47(.023)$ & $.45(.055)$ & $.42(.089)$ \\
\hline Economic & $.54(.019)$ & $.66(.041)$ & $.47(.021)$ & $.50(.054)$ & $.48(.088)$ \\
\hline $\mathrm{N}$ & 9221 & 1810 & 7411 & 661 & 378 \\
\hline $\mathrm{R}^{2}$ & .244 & .476 & .194 & .450 & .179 \\
\hline Lib-Con distance & 2.62 & 3.44 & 2.36 & 3.28 & 2.30 \\
\hline
\end{tabular}

${ }^{*} p>.01$; all other $p$ values $<.01$; standard errors are in parentheses 
Table 4 Issue domains predicted with demographic information in the GSS sample of whites with top $20 \%$ human capital

\begin{tabular}{llll}
\hline & Religious & Racial & Economic \\
\hline Constant & $-.37(.022)$ & $.17(.028)$ & $.52(.030)$ \\
Female & $-.03 *(.018)$ & $-.24(.022)$ & $-.25(.024)$ \\
Age (std) & $.10(.011)$ & $.02 *(.013)$ & $.04(.015)$ \\
Graduate degree & $-.17(.020)$ & $-.24(.024)$ & $-.21(.026)$ \\
Income (std) & $-.08(.008)$ & $.02 *(.010)$ & $.09(.011)$ \\
Married & $.22(.021)$ & $.12(.026)$ & $.14(.028)$ \\
Catholic & $-.10(.022)$ & $-.11(.027)$ & $-.19(.030)$ \\
Not Christian & $-.63(.024)$ & $-.52(.030)$ & $-.47(.033)$ \\
Church (std) & $.47(.010)$ & $.02 *(.012)$ & $.03(.014)$ \\
$\mathrm{N}$ & 7583 & 7849 & 6352 \\
$\mathrm{R}^{2}$ & .415 & .075 & .087 \\
\hline
\end{tabular}

${ }^{*} p>.01$; all other $p$ values $<.01$; standard errors are in parentheses

relating to race, the death penalty, and immigration do often correlate strongly with opinions on economic issues; however, in contrast, racial and economic opinions typically correlate only trivially with religious issues among the bulk of the public.

Despite these small relationships, Americans have increasingly over time used overall liberal and conservative labels in ways that summarize their combined issue opinions. Given the low cross-issue correlations, however, our view is that many people are using these labels as post hoc descriptions or weighted averages of their various issue opinions rather than as descriptions that point to deep psychological tendencies or organizing principles.

In the USA, non-Hispanic whites with high levels of human capital are different. This group has long used liberal-

Table 5 Issue domains predicted with demographic information in the GSS sample excluding whites with top $20 \%$ human capital

\begin{tabular}{llll}
\hline & Religious & Racial & Economic \\
\hline Constant & $.03(.010)$ & $.34(.011)$ & $.24(.013)$ \\
Female & $.07(.008)$ & $-.15(.009)$ & $-.14(.011)$ \\
Age (std) & $.13(.004)$ & $.04(.005)$ & $.08(.005)$ \\
African American & $.00 *(.012)$ & $-1.25(.013)$ & $-.71(.016)$ \\
Latino/Asian/other & $.14(.013)$ & $-.52(.014)$ & $-.30(.017)$ \\
Education (std) & $-.20(.005)$ & $-.01 *(.006)$ & $.14(.007)$ \\
Income (std) & $-.07(.005)$ & $.03(.006)$ & $.16(.007)$ \\
Married & $.18(.009)$ & $.14(.010)$ & $.05(.011)$ \\
Catholic & $-.27(.010)$ & $-.13(.011)$ & $-.13(.013)$ \\
Not Christian & $-.57(.013)$ & $-.22(.014)$ & $-.11(.016)$ \\
Church (std) & $.36(.004)$ & $-.03(.005)$ & $.04(.006)$ \\
$\mathrm{N}$ & 36,253 & 37,170 & 29,885 \\
$\mathrm{R}^{2}$ & .360 & .246 & .138 \\
\hline
\end{tabular}

${ }^{*} p>.01$; all other $p$ values $<.01$; standard errors are in parentheses conservative labels as useful summaries of their issue opinions and shown a meaningful degree of left-right correspondence between religious and racial/economic issue domains. Further, this group has recently experienced a substantial rise in this cross-issue correspondence.

Figure 2 summarizes these results, plotting the average of the "Religious-Economic" and "Religious-Racial" correlations from Table 1 against the "Lib-Con distance" values from Table 2 (i.e., the number of units difference in ideological labels predicted between people with consistently conservative issue opinions and people with consistently liberal issue opinions). For the GSS results, we plotted values for whites with top $20 \%$ human capital and, separately, all others (including non-whites and anyone with bottom $80 \%$ human capital). We included separate plots for the time periods 1980 to 1991, 1993 to 2002, and 2004 to 2014. For our college student sample from 2007, we plotted values separately for whites and non-whites.

As shown in Fig. 2, most Americans (the "GSS: Others" data points, including all sample members other than whites with top $20 \%$ human capital) show very little issue correspondence across religious and racial/economic domains but do show an increasing tendency over time to use ideological labels as useful summaries of issue opinions. Similarly, our nonwhite student sample shows almost no issue correspondence, yet this sample contains individuals who on average tend to use ideological labels that accurately summarize their combined issue positions. These populations are, as we described in Fig. 1, "not ideological" or "nominally ideological." For whites with top $20 \%$ human capital, in contrast, the results reveal strong use of ideological labels, moderate cross-issue correspondence among white students in 2007 and the GSS samples prior to 2004, and stronger cross-issue correspondence among the GSS sample in years 2004 to 2014. These groups straddle being "nominally ideological" and "genuinely ideological," with only the most recent sample of GSS adults securely landing in the "genuinely ideological" region.

These results undermine views, such as the General Orientations Model, that posit that deep and ancient psychological foundations push individuals into broadly coherent liberal or conservative political issue positions. As Fig. 2 shows, no groups land near the "unknowingly ideological" region in which issues correspond but ideological labels are not used. Further, there are groups in which people show trivial cross-domain issue correspondence and yet use ideological labels as reasonably accurate (post hoc) descriptions of their issue positions.

Similarly, these results undermine strong claims about the causal role of party affiliations in determining basic issue opinions. There is little doubt that party affiliations can play a role in affecting factual and policy judgments (Bartels 2002; Cohen 2003). Yet as the parties have adopted a wider range of issue contrasts, the increasing relationship between 
Table 6 Political items predicted with demographic information in the college student sample

\begin{tabular}{|c|c|c|c|c|c|c|}
\hline & \multicolumn{3}{|l|}{ Whites } & \multicolumn{3}{|l|}{ Non-whites } \\
\hline & Religious & Racial & Economic & Religious & Racial & Economic \\
\hline Constant & $.26(.056)$ & $.57(.078)$ & $.16^{*}(.061)$ & $.14 *(.105)$ & $.03 *(.113)$ & $-.10 *(.119)$ \\
\hline African American & - & - & - & $-.05 *(.116)$ & $-.42(.126)$ & $-.18 *(.134)$ \\
\hline Female & $.02 *(.056)$ & $-.14 *(.078)$ & $-.03 *(.080)$ & $.24(.081)$ & $-.31(.087)$ & $-.11 *(.092)$ \\
\hline School quality (std) & $-.11(.030)$ & $-.22(.041)$ & $-.15(.042)$ & $-.18(.039)$ & $-.14(.042)$ & $-.04 *(.045)$ \\
\hline Income (std) & $-.02 *(.029)$ & $.06^{*}(.041)$ & $.26(.042)$ & $.00 *(.037)$ & $-.03 *(.041)$ & $.10 *(.043)$ \\
\hline Catholic & $-.14 *(.072)$ & $-.31(.101)$ & $.10 *(.104)$ & $-.09 *(.112)$ & $-.31(.121)$ & $.08 *(.127)$ \\
\hline Not Christian & $-.87(.067)$ & $-.53(.094)$ & $-.11 *(.097)$ & $-.29(.108)$ & $-.11 *(.117)$ & $-.10 *(.097)$ \\
\hline Church (std) & $.49(.031)$ & $.01 *(.044)$ & $.07 *(.045)$ & $.43(.039)$ & $.02 *(.042)$ & $.00 *(.044)$ \\
\hline $\mathrm{N}$ & 677 & 670 & 666 & 381 & 381 & 378 \\
\hline $\mathrm{R}^{2}$ & .517 & .091 & .080 & .353 & .116 & .036 \\
\hline
\end{tabular}

$* p>.01$; all other $p$ values $<.01 ;$ standard errors are in parentheses

individuals' party affiliations and issue positions can come from two broad sources: people adopting the issue positions of their party and people changing party affiliations because of their issue opinions. The lack of large or increasing crossdomain issue correlations among the bulk of the public suggests that party selection to fit issue opinions is a large contributor to the increasing party-issue matching (Abrajano \& Hajnal 2015; Achen 2002; Carmines, McIver, \& Stimson 1987; Carsey \& Layman 2006; Highton \& Kam 2011; Sniderman \& Stiglitz 2012).

Some political scientists have stressed that while large portions of the population might not demonstrate wholesale liberal-conservative correspondence across opinion domains,

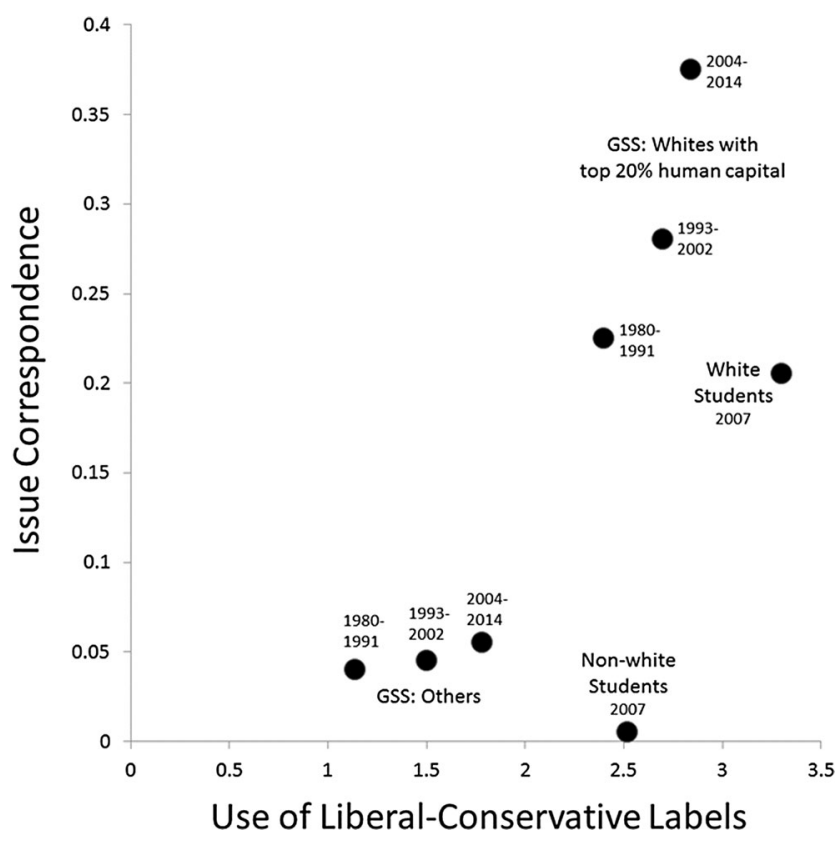

Fig. 2 Summary of ideological results from Table 1 and Table 2 the public nonetheless demonstrates substantial coherence within various opinion domains (Carmines \& Layman 1997; Sniderman \& Bullock 2004). Indeed, our analyses of the demographic predictors of our opinion domains provide additional support for this point. Among most people, church attendance, religion, and education are major predictors of opinions on religious issues. In contrast, race is the dominant predictor of opinions on racial issues, and race and socioeconomic status are major predictors of opinions on economic issues. Public opinion, then, though not often driven by onedimensional ideological commitments, is neither random nor irrational. Each opinion domain has strong connections with the real-life features that in part determine people's interests in the outcomes of these policy contests (Weeden \& Kurzban 2014).

Even among whites with top $20 \%$ human capital-the group that shows the greatest trend towards ideological alignment - there are important demographic differences in issue opinions. This group, however, shows more cross-issue demographic relevance than the rest of the population. In particular, whether one is a Christian or not is particularly important for whites with high human capital; this factor strongly predicts not only religious opinions but also racial and economic opinions. Interestingly, while the GSS adults showed strong evidence of the Christian/non-Christian divide for economic opinions among whites with high human capital, our white college student sample did not-for them, similar to the bulk of the GSS sample, socioeconomic status and race remained the dominant predictors of economic opinions.

\section{Conclusion}

In contrast to the General Orientations Model (Haidt 2012; Hibbing, Smith, \& Alford 2013, 2014; Jost, Federico, \& 
Napier 2009; Pinker 2002; Tuschman 2013), we view an evolutionary approach to political psychology as fruitfully grounded in a Domain-Specific Model. According to this view, people's (fitness) interests drive their issue opinions and people support political coalitions that represent their favored policy outcomes (Petersen 2015; Weeden \& Kurzban 2014).

In this paper, we reviewed evidence that the bulk of the US population shows little tendency to align opinions on a single left-right axis across religious and racial/economic domains. This lack of liberal-conservative alignment persists despite an increasing tendency for the public to choose ideological labels and party affiliations that best represent their opinions across various issue domains. Yet there remains a core cohesiveness to the public's issue opinions in the relationships between particular issue domains and relevant, real-life, domainspecific demographics.

We also find one notable and clear exception: whites with high human capital. While the public as a whole maintains roughly coherent issue opinions given their fundamental demographics and tends these days to support the party coalition representing their various opinions, whites with high human capital have gone further; they have, particularly in the past decade, brought their various opinion domains into strong leftright alignment as the party coalitions have similarly adopted strong left-right forms.

We have not attempted to solve the puzzle this presents, why whites with high human capital have tended to bring their various opinions into coalitional alignment while the bulk of the public has not. Why, for example, do African Americans typically support Democrats without bringing their views on religious issues into stronger liberal alignment or why do white churchgoers with less human capital typically support Republicans without bringing their views on economic issues into stronger conservative alignment? Instead, our task has been more limited. It has been to show that the recent ideological alignment among whites with high human capital is not, in fact, an appropriate foundation on which to propose universal theories of human nature.

\section{References}

Abrajano, M., \& Hajnal, Z. L. (2015). White backlash: immigration, race, and American politics. Princeton: Princeton University Press.

Achen, C. C. (2002). Parental socialization and rational party identification. Political Behavior, 24, 151-70.

Bartels, L. M. (2002). Beyond the running tally: partisan bias in political perceptions. Political Behavior, 24, 117-50.

Carmines, E. G., Ensley, M. J., \& Wagner, M. W. (2012). Who fits the left-right divide? Partisan polarization in the American electorate. American Behavioral Scientist, 56, 1631-1653.
Carmines, E. G., \& Layman, G. C. (1997). Value priorities, partisanship, and electoral choice: the neglected case of the United States. Political Behavior, 19, 283-316.

Carmines, E. G., McIver, J. P., \& Stimson, J. A. (1987). Unrealized partisanship: a theory of dealignment. The Journal of Politics, 49, 376-400.

Carsey, T. M., \& Layman, G. C. (2006). Changing sides or changing minds? Party identification and policy preferences in the American electorate. American Journal of Political Science, 50, 464-77.

Claassen, C., Tucker, P., \& Smith, S. S. (2015). Ideological labels in America. Political Behavior, 37, 253-278.

Cohen, G. L. (2003). Party over policy: the dominating impact of group influence on political beliefs. Journal of Personality and Social Psychology, 85, 808-22.

Converse, P. E. (1964). The nature of belief systems in mass publics. In D. E. Apter (Ed.), Ideology and discontent. New York: Free Press.

Ellis, C., \& Stimson, J. A. (2012). Ideology in America. Cambridge: Cambridge University Press.

Feldman, S., \& Johnston, C. (2014). Understanding the determinants of political ideology: implications of structural complexity. Political Psychology, 35, 337-358.

Gelman, A. (2015). How better educated whites are driving political polarization. In D. J. Hopkins \& J. Sides (Eds.), Political polarization in american politics. New York: Bloomsbury Academic.

Haidt, J. (2012). The righteous mind: why good people are divided by politics and religion. New York: Pantheon Books.

Hibbing, J. R., Smith, K. B., \& Alford, J. R. (2013). Predisposed: liberals, conservatives, and the biology of political differences. New York: Routledge.

Hibbing, J. R., Smith, K. B., \& Alford, J. R. (2014). Differences in negativity bias underlie variations in political ideology. Behavioral and Brain Sciences, 37, 297-350.

Highton, B., \& Kam, C. D. (2011). The long-term dynamics of partisanship and issue orientations. The Journal of Politics, $73,202-215$.

Hussey, L. S. (2012). Polarized politics and citizen disengagement: the role of belief systems. American Politics Research, 40, 85115.

Jacoby, W. G. (1991). Ideological identification and issue attitudes. American Journal of Political Science, 35, 178-205.

Jessee, S. A. (2012). Ideology and spatial voting in American elections. Cambridge University Press.

Jost, J. T., Federico, C. M., \& Napier, J. L. (2009). Political ideology: its structure, functions, and elective affinities. Annual Review of Psychology, 60, 307-337.

Klar, S. (2014). A multidimensional study of ideological preferences and priorities among the American public. Public Opinion Quarterly, 78, 344-359.

Kurzban, R. (2010). Why everyone (else) is a hypocrite: evolution and the modular mind. Princeton: Princeton University Press.

Kurzban, R., Dukes, A., \& Weeden, J. (2010). Sex, drugs and moral goals: reproductive strategies and views about recreational drugs. Proceedings of the Royal Society B, 277, 35013508 .

Lopez, A. C., \& McDermott, R. (2012). Adaptation, heritability, and the emergence of evolutionary political science. Political Psychology, 33, 343-362.

Noel, H. (2013). Political ideologies and political parties in America. Cambridge University Press.

Petersen, M. B. (2015). Evolutionary political psychology. In D. Buss (Ed.), The handbook of evolutionary psychology (2nd ed., Vol. 2). Hoboken: Wiley.

Pinker, S. (2002). The blank slate: the modern denial of human nature. New York: Penguin. 
Sniderman, P. M., \& Bullock, J. (2004). A consistency theory of public opinion and political choice: the hypothesis of menu dependence. In W. E. Saris \& P. M. Sniderman (Eds.), Studies in public opinion: attitudes, nonattitudes, measurement error, and change. Princeton University Press: Princeton.

Sniderman, P. M., \& Stiglitz, E. H. (2012). The reputational premium: a theory of party identification and policy reasoning. Princeton: Princeton University Press.

Stimson, J. A. (1975). Belief systems: constraint, complexity, and the 1972 election. American Journal of Political Science, 19, 393-417.

Treier, S., \& Hillygus, D. S. (2009). The nature of political ideology in the contemporary electorate. Public Opinion Quarterly, 73, 679-703.
Tuschman, A. (2013). Our political nature: the evolutionary origins of what divides us. Amherst, New York: Prometheus Books.

Verhulst, B., Hatemi, P. K., \& Eaves, L. J. (2012). Disentangling the importance of psychological predispositions and social constructions in the organization of American political ideology. Political Psychology, 3, 375-393.

Weeden, J. (2003). Genetic interests, life histories, and attitudes towards abortion. Unpublished $\mathrm{PhD}$ dissertation.

Weeden, J., Cohen, A. B., \& Kenrick, D. T. (2008). Religious attendance as reproductive support. Evolution and Human Behavior, 29, 327-334.

Weeden, J., \& Kurzban, R. (2014). The hidden agenda of the political mind: how self-interest shapes our opinions and why we won't admit it. Princeton: Princeton University Press. 